\title{
Knowledge, attitudes, and practices regarding cervical cancer and screening among Ethiopian health care workers
}

This article was published in the following Dove Press journal:

International Journal of Women's Health

31 July 2015

Number of times this article has been viewed

\author{
Catherine M Kress' \\ Lisa Sharling ${ }^{2}$ \\ Ashli A Owen-Smith ${ }^{3}$ \\ Dawit Desalegn ${ }^{4}$ \\ Henry M Blumberg ${ }^{2}$ \\ Jennifer Goedken' \\ 'Department of Gynecology and \\ Obstetrics, ${ }^{2}$ Division of Infectious \\ Diseases, Department of Medicine, \\ ${ }^{3}$ Department of Behavioral Sciences \\ and Health Education, Rollins School \\ of Public Health, Emory University, \\ Atlanta, GA, USA; ${ }^{4}$ Department \\ of Gynecology and Obstetrics, Addis \\ Ababa University School of Medicine, \\ Addis Ababa, Ethiopia
}

Background: Though cervical cancer incidence has dramatically decreased in resource rich regions due to the implementation of universal screening programs, it remains one of the most common cancers affecting women worldwide and has one of the highest mortality rates. The vast majority of cervical cancer-related deaths are among women that have never been screened. Prior to implementation of a screening program in Addis Ababa University-affiliated hospitals in Ethiopia, a survey was conducted to assess knowledge of cervical cancer etiology, risk factors, and screening, as well as attitudes and practices regarding cervical cancer screening among women's health care providers.

Methods: Between February and March 2012 an anonymous, self-administered survey to assess knowledge, attitudes, and practices related to cervical cancer and its prevention was distributed to 334 health care providers at three government hospitals in Addis Ababa, Ethiopia and three Family Guidance Association clinics in Awassa, Adama, and Bahir Dar. Data were analyzed using SPSS software and chi-square test was used to test differences in knowledge, attitudes, and practices across provider type.

Results: Overall knowledge surrounding cervical cancer was high, although awareness of etiology and risk factors was low among nurses and midwives. Providers had no experience performing cervical cancer screening on a routine basis with $<40 \%$ having performed any type of cervical cancer screening. Reported barriers to performing screening were lack of training $(52 \%)$ and resources (53\%); however the majority $(97 \%)$ of providers indicated cervical cancer screening is an essential part of women's health care.

Conclusion: There is a clear need among women's health care providers for education regarding cervical cancer etiology, risk factors and for training in low-tech, low-cost screening methods. Meeting these needs and improving the infrastructure necessary to implement appropriate screening programs is essential to reduce the burden of cervical cancer in Ethiopia.

Keywords: cervical cancer, visual inspection, acetic acid, cryotherapy, Ethiopia

\section{Background}

Cervical cancer is the third most common cancer affecting women worldwide and responsible for an estimated 265,000 deaths annually worldwide, $87 \%$ occurring in low-resource countries. ${ }^{1,2}$ The disparity in cervical cancer diagnosis and subsequent mortality between high- and low-resource countries is due largely to the low rate of screening for pre-invasive cervical disease and limited treatment options in lowresource settings. Cervical cancer's long latency and recognizable pre-cancerous lesions make screening a particularly effective way of prevention as pre-cancerous lesions, once identified, can be expectantly managed or treated safely and inexpensively in an
Correspondence: Jennifer Goedken Department of Gynecology and Obstetrics, Emory University, 69 Jesse Hill Jr Dr SE Atlanta, GA 30303, USA

$\mathrm{Tel}+\mathrm{I} 40425$ I 8800

$\mathrm{Fax}+$ I 4045213589

Email jgoedke@emory.edu 
outpatient setting. ${ }^{3}$ The majority of cervical cancer deaths occur in women who are never screened or treated and in women with well-described sexual and reproductive risk factors, such as an early sexual debut, a history of multiple sexual partners, and a high number of live births. ${ }^{4,5}$

The age adjusted incidence of cervical cancer in Ethiopia is 26.4 per 100,000 women, which is second only to breast cancer. ${ }^{6}$ Roughly 4,732 women die of cervical cancer each year, the highest cancer-related mortality rate (10.9 per 100,000) among Ethiopian women. ${ }^{6}$ However these estimates are likely an underestimate of cervical cancer cases and deaths due to a low level of awareness, ${ }^{7,8}$ limited access to screening and diagnostic services, ${ }^{9}$ and the lack of a national cancer registry. The government of Ethiopia recognizes the urgency of this situation and has prioritized it by recently launching a national strategic action plan for cervical cancer prevention and control.

Currently, there is no national cervical cancer screening program in Ethiopia. There is limited use of Papanicolaou (pap) smears, mostly in private clinical settings and some community health centers such as Family Guidance Association (FGA) clinics. However, pap smears have proven to be difficult in resource-limited settings due to cost, limited cytopathology resources, and inability for consistent patient follow-up. Studies suggest that cervical cancer screening programs in low-resource settings are most successful and cost-effective when they require few visits and offer a "screen and treat" (single-visit) approach. ${ }^{10}$ The aim of this study was to assess the knowledge, awareness, attitudes, and practices around cervical cancer and its prevention among Ethiopian health care providers in preparation for a "screen and treat" demonstration project at Addis Ababa University affiliated teaching hospitals.

\section{Methods}

This study was reviewed by the Institutional Review Boards (IRBs) at Emory University and Addis Ababa University and determined to be exempt. During a 6-week period in February and March 2012, self-administered, anonymous, multiplechoice surveys were distributed to health care providers who self-identified as providing care to female patients of reproductive age at three university-affiliated public teaching hospitals in Addis Ababa (Tikur Anbessa Hospital, St Paul's Hospital, and Gandhi Memorial Hospital), and three FGA clinics in Awassa, Adama, and Bahir Dar, Ethiopia. Survey participants included nurses, midwives, medical students, general practitioners, internists, pediatricians, and obstetricians/gynecologists. Each participant received a written explanation about the objectives of the study and was verbally consented for participation. The survey, as well as the information about the study was available in both English and Amharic.

Participants were recruited via direct contact by one of the study authors (CMK) or by the head nurses of each department. The survey contained true-false and multiple-choice questions including 17 questions assessing knowledge, 16 assessing attitudes, and 15 assessing individual practice or experience related to cervical cancer prevention. Seven questions collected participant demographics. All data were entered into the Research Electronic Data Capture (REDCap) database. ${ }^{11}$ Analyses were performed using the statistical package SPSS (version 20.0; IBM Corporation, Armonk, NY, USA). Differences in knowledge, attitudes, and practice across provider type were evaluated using a $\chi^{2}$ test where a $P<0.05$ was considered statistically significant.

\section{Results and discussion}

The knowledge, attitudes, and practices survey was completed by 335 health care providers however two surveys were excluded from analysis due to missing occupation. The 333 surveys included in the analysis were collected from 84 (25\%) physicians, 159 (48\%) nurses, 38 midwives $(11 \%)$, and $52(16 \%)$ medical students. The majority of respondents $(92 \%)$ were from one of the three government hospitals in Addis Ababa, and an additional 26 respondents were employed at FGA clinics and included three doctors and 23 nurses and midwives. Across health care settings the majority of respondents were nurses or midwives $(59 \%)$, female $(65 \%)$, and less than 36 years of age $(75 \%)$ with a median age of 28 years. Further demographic characteristics are shown in Table 1.

\section{Knowledge}

General awareness of cervical cancer was high among all respondents with $81 \%$ identifying cervical cancer as an important cause of morbidity and mortality for women in Ethiopia (Table 2). Almost all providers recognized cervical cancer as a preventable disease $(85 \%)$, with a detectable precancerous stage ( $87 \%$ ) and understood the role of cervical cancer screening in detecting precancerous lesions (91\%). Awareness of the link between human papilloma viruses (HPV) and cervical cancer was high among all doctors (96\%) and medical students ( $92 \%$; Table 3 ) and the knowledge that the virus is spread sexually was nearly as high in these two groups (93\% and 88\% respectively). Although HPV was correctly identified as a risk factor for cervical cancer by 
Table I Demographics of participants

\begin{tabular}{|c|c|c|c|c|}
\hline & $\begin{array}{l}\text { Medical doctors }{ }^{a} \\
(n=84)\end{array}$ & $\begin{array}{l}\text { Medical students } \\
(\mathrm{n}=52)\end{array}$ & $\begin{array}{l}\text { Nurses and midwives } \\
(\mathrm{n}=197)\end{array}$ & $\begin{array}{l}\text { Total } \\
(\mathrm{n}=333)\end{array}$ \\
\hline \multicolumn{5}{|l|}{ Age (years) } \\
\hline$<25$ & $13(15)$ & $46(88)$ & $45(23)$ & $104(3 \mathrm{I})$ \\
\hline $26-35$ & $59(70)$ & $6(12)$ & $79(40)$ & $144(44)$ \\
\hline $36-45$ & $8(10)$ & $0(0)$ & $54(27)$ & $62(19)$ \\
\hline$\geq 46$ & $4(5)$ & $0(0)$ & $17(9)$ & $21(6)$ \\
\hline Missing/unknown & $0(0)$ & $0(0)$ & $2(1)$ & $2(1)$ \\
\hline \multicolumn{5}{|l|}{ Sex } \\
\hline Male & $59(70)$ & $27(52)$ & $30(15)$ & $116(35)$ \\
\hline Female & $25(30)$ & $25(48)$ & $167(85)$ & $217(65)$ \\
\hline \multicolumn{5}{|l|}{ Setting } \\
\hline Hospital & $81(96)$ & $52(100)$ & I74 (88) & $307(92)$ \\
\hline FGA clinic & $3(4)$ & $0(0)$ & $23(12)$ & $26(8)$ \\
\hline \multicolumn{5}{|l|}{ Primary language } \\
\hline Amharic & $65(77)$ & $42(8 I)$ & $152(77)$ & $259(78)$ \\
\hline Oromia & $6(7)$ & $6(12)$ & $22(\mathrm{II})$ & $34(10)$ \\
\hline Somali & $6(7)$ & $2(4)$ & $13(7)$ & $21(6)$ \\
\hline Tigringa & $I(I)$ & $0(0)$ & $\mathrm{I}(\mathrm{I})$ & $2(I)$ \\
\hline Other & $4(5)$ & $2(4)$ & $3(2)$ & $9(3)$ \\
\hline Missing/unknown & $2(2)$ & $0(0)$ & $6(3)$ & $8(2)$ \\
\hline \multicolumn{5}{|l|}{ Religion } \\
\hline Ethiopian Orthodox & $59(70)$ & 38 (7I) & $132(66)$ & $227(69)$ \\
\hline Muslim & $9(\mathrm{II})^{\prime}$ & $6(12)$ & $25(13)$ & $40(12)$ \\
\hline Protestant & $11(13)$ & $6(12)$ & $37(19)$ & $54(16)$ \\
\hline Other & $4(5)$ & $3(6)$ & $I(I)$ & $8(2)$ \\
\hline Missing/unknown & $I(1)$ & I (2) & $2(1)$ & $4(1)$ \\
\hline \multicolumn{5}{|c|}{ Number of years on the job } \\
\hline$<1$ & $23(27)$ & $2(4)$ & $13(7)$ & $38(11)$ \\
\hline $\mathrm{I}-5$ & $46(55)$ & $26(50)$ & $58(29)$ & $130(39)$ \\
\hline $6-10$ & $6(7)$ & $24(46)$ & $65(33)$ & $95(29)$ \\
\hline$>10$ & $7(8)$ & $0(0)$ & $61(31)$ & $68(20)$ \\
\hline Missing/unknown & $2(2)$ & $0(0)$ & $0(0)$ & $2(1)$ \\
\hline
\end{tabular}

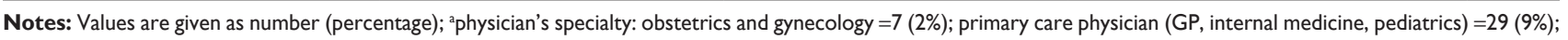
residents $=48$ ( $14 \%)$; ${ }^{b}$ nurses $=159(48 \%)$ and midwives $=38$ ( 1 I\%).

Abbreviation: FGA, Family Guidance Association.

Table 2 Knowledge of cervical cancer etiology and prevention

\begin{tabular}{|c|c|c|c|c|c|}
\hline \multirow[t]{2}{*}{ Question } & $\begin{array}{l}\text { Medical } \\
\text { doctors } \\
(n=84)\end{array}$ & $\begin{array}{l}\text { Medical } \\
\text { students } \\
(n=52)\end{array}$ & $\begin{array}{l}\text { Nurses and } \\
\text { midwives } \\
(n=197)\end{array}$ & \multirow[t]{2}{*}{$\begin{array}{l}\text { Total } \\
(n=333)\end{array}$} & \multirow[t]{2}{*}{$P$-value ${ }^{a}$} \\
\hline & \multicolumn{3}{|c|}{ Correct answer ${ }^{a}$} & & \\
\hline $\begin{array}{l}\text { Cervical cancer is one of the leading causes of death in } \\
\text { women worldwide - True }\end{array}$ & $73(87)$ & $45(87)$ & $153(78)$ & $27 \mid(8 I)$ & 0.038 \\
\hline Cervical cancer is preventable - True & $82(98)$ & $50(96)$ & $|5|(77)$ & $283(85)$ & $<0.001$ \\
\hline It is possible to detect pre-cancerous cervical cells - True & $77(92)$ & $50(96)$ & $162(82)$ & $289(87)$ & 0.019 \\
\hline $\begin{array}{l}\text { The purpose of screening for cervical cancer is to detect } \\
\text { pre-cancerous changes - True }\end{array}$ & $83(99)$ & $50(96)$ & I7| (87) & $304(91)$ & 0.012 \\
\hline If untreated cervical cancer is fatal - True & $78(93)$ & $47(90)$ & $152(77)$ & $277(83)$ & 0.016 \\
\hline $\begin{array}{l}\text { Cervical cancer is caused by a virus that is spread } \\
\text { sexually - True }\end{array}$ & $78(93)$ & $46(88)$ & $63(32)$ & $187(56)$ & $<0.001$ \\
\hline There is a vaccine that can prevent cervical cancer - True & $64(76)$ & $23(44)$ & $36(18)$ & $123(37)$ & $<0.001$ \\
\hline Cervical cancer is not curable - False & $56(87)$ & $28(54)$ & $88(45)$ & $172(52)$ & 0.013 \\
\hline $\begin{array}{l}\text { Cervical cancer is most common among women in their } \\
20 \text { s - False }\end{array}$ & $78(93)$ & $40(77)$ & $133(68)$ & $25 \mathrm{I}(75)$ & $<0.00 \mathrm{I}$ \\
\hline $\begin{array}{l}\text { For cervical cancer, the progression of pre-cancerous } \\
\text { cells to cancer can take 10-20 years - True }\end{array}$ & $78(93)$ & $4 \mathrm{I}(79)$ & $70(36)$ & $189(57)$ & $<0.001$ \\
\hline $\begin{array}{l}\text { Cervical cancer can usually be found at an early stage } \\
\text { because of the obvious symptoms - False }\end{array}$ & $66(79)$ & $30(58)$ & $85(43)$ & |8| (54) & $<0.001$ \\
\hline
\end{tabular}

Notes: Values are given as number (percentage); adifference in knowledge between group. 
Table 3 Knowledge of risk factors for cervical cancer

\begin{tabular}{|c|c|c|c|c|c|}
\hline \multirow[t]{2}{*}{ Question } & $\begin{array}{l}\text { Medical } \\
\text { doctors }(n=84)\end{array}$ & $\begin{array}{l}\text { Medical } \\
\text { students }(n=52)\end{array}$ & $\begin{array}{l}\text { Nurses and } \\
\text { midwives }(n=197)\end{array}$ & \multirow[t]{2}{*}{$\begin{array}{l}\text { Total } \\
(n=333)\end{array}$} & \multirow[t]{2}{*}{$P$-value } \\
\hline & \multicolumn{3}{|l|}{ Correct answer ${ }^{\mathrm{a}}$} & & \\
\hline Correctly identified all four risk factors & $59(70)$ & $25(48)$ & $70(36)$ & $156(47)$ & $<0.001$ \\
\hline Infection with the human immunodeficiency virus (HIV) & $78(93)$ & $39(75)$ & $123(62)$ & $240(72)$ & $<0.001$ \\
\hline Infection with human papilloma virus (HPV) & $81(96)$ & $48(92)$ & $147(75)$ & $276(83)$ & $<0.00 \mathrm{I}$ \\
\hline Having multiple sex partners & $80(95)$ & $47(90)$ & $135(69)$ & $262(79)$ & $<0.001$ \\
\hline Smoking cigarettes & $64(76)$ & $34(65)$ & $118(60)$ & $216(65)$ & 0.032 \\
\hline Misidentified at least one non-risk factor & $23(27)$ & $35(67)$ & $120(6 \mid)$ & $179(54)$ & $<0.001$ \\
\hline Poor personal hygiene & $19(23)$ & $29(56)$ & $102(52)$ & $150(45)$ & $<0.001$ \\
\hline Use of intrauterine devices (IUDs) & $6(7)$ & $19(37)$ & $32(16)$ & $57(17)$ & $<0.001$ \\
\hline Use of herbal remedies & $5(6)$ & $7(13)$ & $59(30)$ & $7 \mid(2 I)$ & $<0.001$ \\
\hline Use of tampons & $5(6)$ & $9(17)$ & $26(13)$ & $40(12)$ & 0.102 \\
\hline
\end{tabular}

Notes: ${ }^{a}$ Values are given as number (percentage); bdifference in knowledge between groups.

most nurses and midwives (75\%), only $32 \%$ thought cervical cancer was caused by a virus that was spread sexually, revealing a limited understanding regarding cervical cancer etiology among these providers.

Similarly, only $36 \%$ of nurses and midwives understood the slow progression from precancerous lesions to cancer. Also, only $43 \%$ understood there were no early symptoms of cervical cancer (Table 2).

Knowledge of the major risk factors for cervical cancer was generally high and significantly associated with occupation (Table 3). Less than half of medical students (48\%) and nurses and midwives (36\%), but $70 \%$ of doctors were able to correctly identify all four risk factors $(P<0.001)$. More than half $(54 \%)$ of respondents incorrectly identified at least one non-risk factor for cervical cancer, the most common being poor hygiene $(45 \%)$. There were also significant differences across provider type in the correct identification of the four non-risk factors included in the survey; misidentification was high amongst medical students $(67 \%)$ and nurses/midwives $(61 \%)$ and lowest amongst doctors $(27 \%)(P<0.001$; Table 3).

With respect to screening and prevention of cervical cancer, the majority of respondents ( $92 \%$ ) had heard of the pap smear, but awareness of alternative cervical cancer screening methods was low and differed significantly by provider type (Table 4). For example, only $49 \%$ of all providers had heard of visual inspection with acetic acid (VIA). When stratified by provider type, $82 \%$ of doctors were familiar with VIA compared with $60 \%$ of medical students and $31 \%$ of nurses and midwives (Table 4; $P<0.001$ ). Knowledge of a vaccine to prevent cervical cancer was also lower among nurses and midwives (18\%) compared to medical students (44\%) and higher among doctors $(76 \%)$ (Table $2 ; P<0.001)$.

\section{Attitudes}

Awareness of the severity of cervical cancer and the importance of screening was very high among all respondents with $98 \%$ stating that cervical cancer is a serious disease and $97 \%$ agreeing that cervical cancer screening should be an essential part of women's health care (Table 4). Although $89 \%$ of respondents thought that a cervical cancer screening program should be started in their community, $52 \%$ of all respondents reported that they had inadequate training to screen (Table 5).

Additional barriers to cervical cancer screening included a lack of equipment and supplies (53\%), lack of laboratory resources $(41 \%)$, expense to patients $(42 \%)$, inability to follow-up with patients (37\%), and more pressing health problems of patients (37\%). Patient dislike and refusal (15\%), difficulty of screening (19\%), and health care provider time constraints (15\%) were considered lesser barriers. With the exception of medical students perceiving patient dislike and refusal as a barrier at approximately three times the rate $(30 \%)$ than the other providers $\operatorname{did}(P=0.016)$, there were no significant differences in perceived barriers by health care provider type (Table 5).

\section{Practices}

Only $22 \%$ of health care providers reported having performed a pap smear. Of those who reported having performed a pap smear, only $28 \%$ had done more than ten. Even fewer health care providers $(11 \%)$ reported experience with VIA and of those, 29\% had performed it more than ten times (Figure 1).

Cervical cancer screening was low among the 217 female health care providers surveyed with only $17 \%$ reporting ever having been screened for cervical cancer. However, 30\% of respondents over the age of 35 had reported a history of screening. 
Table 4 Attitudes, awareness, and experiences related to cervical cancer screening

\begin{tabular}{|c|c|c|c|c|c|}
\hline \multirow[t]{2}{*}{ Question } & $\begin{array}{l}\text { Medical doctors } \\
(\mathrm{n}=\mathbf{8 4})\end{array}$ & $\begin{array}{l}\text { Medical students } \\
(\mathrm{n}=52)\end{array}$ & $\begin{array}{l}\text { Nurses and midwives } \\
(\mathrm{n}=197)\end{array}$ & \multirow[t]{2}{*}{$\begin{array}{l}\text { Total } \\
(n=333)\end{array}$} & \multirow[t]{2}{*}{$P$-value ${ }^{b}$} \\
\hline & \multicolumn{3}{|c|}{ Strongly agree/agree $^{a}$} & & \\
\hline \multicolumn{6}{|l|}{ Cervical cancer screening is an essential part } \\
\hline of women's health care ${ }^{c}$ & $84(100)$ & $50(96)$ & $184(95)$ & $329(97)$ & 0.136 \\
\hline Cervical cancer is a very serious disease $^{d}$ & $84(100)$ & $52(100)$ & $184(96)$ & $320(98)$ & 0.055 \\
\hline A cervical cancer screening program should & $84(100)$ & $49(94)$ & $158(83)$ & $291(89)$ & $<0.001$ \\
\hline \multicolumn{6}{|l|}{ be started in my community ${ }^{e}$} \\
\hline \multicolumn{6}{|l|}{ Female respondents ${ }^{f}$} \\
\hline Have you ever received a pap smear & $8(32)$ & $0(0)$ & $29(18)$ & $37(17)$ & 0.035 \\
\hline \multicolumn{6}{|l|}{ Have you ever heard of the following tests } \\
\hline Pap smear & $80(95)$ & $51(98)$ & $175(89)$ & $306(92)$ & 0.041 \\
\hline Human papilloma virus DNA testing & $72(86)$ & $40(77)$ & $69(35)$ & I8I (54) & $<0.00$ I \\
\hline Liquid-based cytology & $55(65)$ & $19(37)$ & $4 I(2 I)$ & $115(35)$ & $<0.00$ I \\
\hline Visual inspection with acetic acid & $69(82)$ & $31(60)$ & $62(3 I)$ & $163(49)$ & $<0.001$ \\
\hline Visual inspection with Lugol's solution & $68(81)$ & $37(7 \mathrm{I})$ & $51(26)$ & $156(47)$ & $<0.00$ I \\
\hline $\begin{array}{l}\text { Have you ever diagnosed a patient with cervical } \\
\text { cancerg }\end{array}$ & $33(42)$ & $7(14)$ & $29(15)$ & $69(22)$ & $<0.001$ \\
\hline $\begin{array}{l}\text { Have you ever diagnosed pre-cancerous cervical } \\
\text { lesions in a patient }{ }^{\mathrm{h}}\end{array}$ & $56(67)$ & $10(19)$ & $52(27)$ & $118(36)$ & $<0.001$ \\
\hline \multicolumn{6}{|l|}{ Have you ever treated pre-cancerous cervical } \\
\hline lesions in a patient $\mathrm{t}^{\mathrm{i}}$ & $26(31)$ & $5(10)$ & $26(14)$ & $57(18)$ & $<0.001$ \\
\hline
\end{tabular}

Table 5 Perceived barriers to providing cervical cancer screening

\begin{tabular}{|c|c|c|c|c|c|c|}
\hline \multirow[t]{2}{*}{ Question } & $\begin{array}{l}\text { Medical } \\
\text { doctors } \\
(n=84)\end{array}$ & $\begin{array}{l}\text { Medical } \\
\text { students } \\
(n=52)\end{array}$ & $\begin{array}{l}\text { Nurses and } \\
\text { midwives } \\
(n=197)\end{array}$ & \multirow[t]{2}{*}{$\begin{array}{l}\text { Total } \\
(n=333)\end{array}$} & \multirow[t]{2}{*}{$P$-value ${ }^{b}$} & \multirow[t]{2}{*}{$\begin{array}{l}\text { No } \\
\text { answer }\end{array}$} \\
\hline & \multicolumn{3}{|c|}{ "Quite a bit" or "a lot" of barrier(s) } & & & \\
\hline My patients dislike/refuse screening & $8(10)$ & II (30) & $22(13)$ & $4 I(15)$ & 0.016 & $52(16)^{c}$ \\
\hline $\begin{array}{l}\text { My patients have more pressing } \\
\text { health problems }\end{array}$ & $32(4 I)$ & $15(43)$ & $54(34)$ & I0I (37) & 0.390 & $59(18)^{d}$ \\
\hline $\begin{array}{l}\text { I have not had the necessary } \\
\text { training in order to screen }\end{array}$ & $37(47)$ & $21(49)$ & $80(55)$ & $148(52)$ & 0.491 & $46(14)^{\mathrm{e}}$ \\
\hline $\begin{array}{l}\text { The screening tests are too } \\
\text { expensive for patients }\end{array}$ & $31(39)$ & $14(37)$ & $75(44)$ & $120(42)$ & 0.590 & $47(14)^{f}$ \\
\hline $\begin{array}{l}\text { I do not have enough time/l am } \\
\text { too busy to screen }\end{array}$ & $9(12)$ & $7(19)$ & $27(16.4)$ & $43(15)$ & 0.532 & $53(16)^{g}$ \\
\hline $\begin{array}{l}\text { I do not have the necessary } \\
\text { equipment/supplies }\end{array}$ & $45(57)$ & $20(56)$ & $79(50)$ & I 44 (53) & 0.593 & $61(18)^{h}$ \\
\hline $\begin{array}{l}\text { The screening procedures are } \\
\text { too difficult }\end{array}$ & $9(12)$ & $5(14)$ & $37(24)$ & $51(19)$ & 0.066 & $65(20)^{i}$ \\
\hline $\begin{array}{l}\text { I do not have the necessary } \\
\text { laboratory resources to screen }\end{array}$ & $36(47)$ & $15(4 \mid)$ & $60(39)$ & III (4I) & 0.452 & $65(20)^{j}$ \\
\hline I do not have the capacity & & & & & & \\
\hline to follow-up patients after screening & $27(35)$ & $16(45)$ & $56(36)$ & $99(37)$ & 0.605 & $66(20)^{k}$ \\
\hline
\end{tabular}

Notes: aThe 4-point scale eliciting the answers "not at all", "somewhat", "quite a bit" and "a lot" was dichotomized to "not at all" or "somewhat" versus "quite a bit" or "a lot" where values are given as number (percentage); 'difference between groups; 'missing values for five doctors, 15 medical students, and 32 nurses and midwives; 'missing values for six doctors, 17 medical students, and 36 nurses and midwives; ${ }^{e}$ missing values for five doctors, nine medical students, and 32 nurses and midwives; ${ }^{f}$ missing values for five doctors, 14 medical students and 28 nurses and midwives; ${ }^{g}$ missing values for seven doctors, 15 medical students, and 31 nurses and midwives; ${ }^{\mathrm{h}}$ missing values for five doctors, 16 medical students and 40 nurses and midwives; 'missing values for seven doctors, 17 medical students and $4 \mathrm{I}$ nurses and midwives; 'imissing values for eight doctors, 15 medical students and 42 nurses and midwives; ${ }^{\mathrm{k}}$ missing values for ten doctors, 16 medical students and 43 nurses and midwives. 


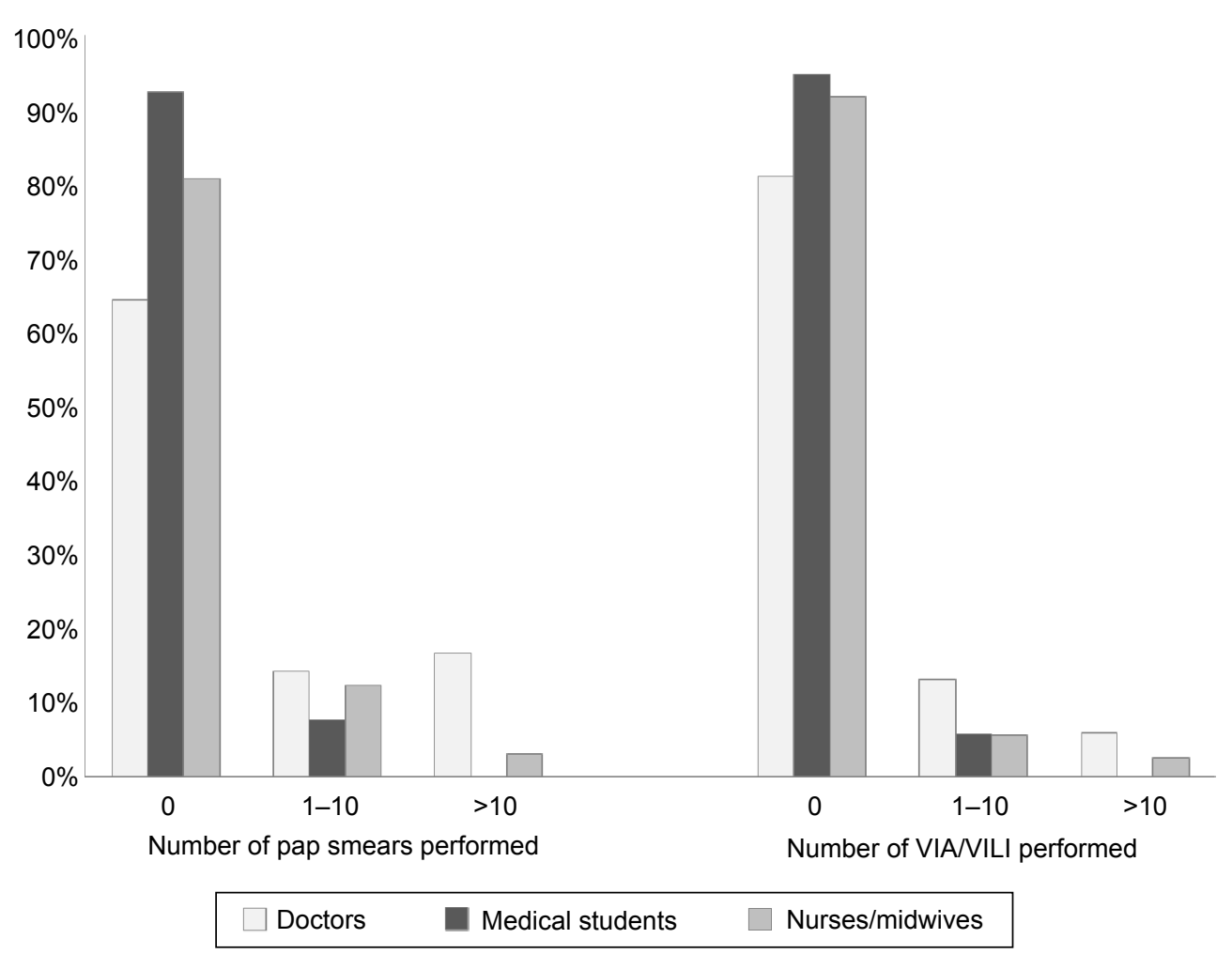

Figure I Number of cervical cancer screening procedures performed by provider type.

Note: Proportion of medical doctors, medical students and nurses and midwives having performed pap smear, visual inspection with acetic acid (VIA) or visual inspection with Lugol's iodine (VILI).

The purpose of this study was to assess baseline knowledge and awareness of cervical cancer and cervical cancer screening, as well as attitudes towards cervical cancer screening practices among health care providers in Ethiopia involved in women's primary care. This study was undertaken in order to inform the development of a pilot training program in VIA and cryotherapy at Tikur Anbessa (Black Lion) Hospital and St Paul's Hospital, two large teaching hospitals in Addis Ababa. Our survey found significant deficits in the understanding of cervical cancer etiology, pathophysiology, and risk factors among nurses and midwives. This deficiency could have implications for future screening programs since these providers would likely play a principal role in patient education and implementation of a cervical cancer screening program in Ethiopia. Fortunately, responses indicated recognition by those providers of the need for more education about cervical cancer.

Importantly, a clear understanding of the link between HPV infection and cervical cancer, as well as an awareness of the availability of HPV testing and a vaccine against HPV were low among non-physician providers. As HPV testing and vaccination become available in Ethiopia, uptake will likely be strongly influenced by information received from non-physician health care providers. Therefore, increasing such awareness among this group of providers will be critical to the success any public health initiatives. Prior studies in east Africa have demonstrated numerous misconceptions about the HPV vaccine, but high acceptability of the vaccine when accurate information was provided from a trusted source. ${ }^{12}$ Currently HPV vaccines are only beginning to be available and only in the private sector in Ethiopia and although our study did not assess specific knowledge about HPV vaccines or attitudes regarding their use, this will be important to ascertain as the vaccine becomes more widely available in the future.

Despite the success of cytology-based screening programs in the developed world, they rarely exist in low-resource regions and there is a lack of laboratory infrastructure for processing and reading pap smears. When they are performed in low-resource settings they are frequently ineffective, due to inadequate technical and financial resources. ${ }^{13}$ The need for follow-up visits with cytology-based screening programs is problematic in low-resource settings due to barriers such as difficulties in contacting patients, transportation availability and cost, clinic hours, and childcare needs. VIA and rapid, low-cost HPV DNA testing ${ }^{14}$ are two cervical cancer screening 
alternatives to cytology that do not require follow-up visits and have been successfully used in low and medium resource settings. ${ }^{14-22}$ This study revealed however, that the vast majority of nurses and midwives had never heard of any screening methods other than the pap smear. Education about these alternative approaches is critical and should be made a training priority for health care providers involved in women's primary care as steps are taken to scale up screening in Ethiopia.

\section{Conclusion}

Despite almost no experience with cervical cancer screening methods of any sort, our results indicate a high level of interest among all providers in receiving training and incorporating cervical cancer screening in future practice. Importantly, the need for screening was identified by all providers. This is consistent with a recent study conducted at Tikur Anbessa hospital which concluded that:

Primary prevention measures, vaccination against HPV and screening, should be initiated and expanded to reduce morbidity from cervical cancer and subsequent costs in both human lives and money resources $[\ldots] .{ }^{9}$

Barriers to screening most commonly cited in our study centered on the lack of resources and difficulty with follow-up, as opposed to health care provider or patient objection and lack of time or interest, which were not seen as barriers by most. These findings speak to the utility of a simple, inexpensive, "screen and treat" approach to cervical cancer prevention such as VIA and immediate same-day cryotherapy, which can be performed safely and effectively by midlevel providers in a primary setting. ${ }^{19,23,24}$

\section{Acknowledgments}

Supported in part by the NIH/FIC (Emory-Ethiopia Global Interdisciplinary Partnership; 1 R24 TW008825-01), the Medical Education Partnership Initiative (MEPI)-Ethiopia (T84HA21124), the Emory Global Health Institute, and the Emory University Woodruff Health Sciences Center, Center for Global Cancer Treatment and Prevention. We are very grateful to the Addis Ababa University for their support of this study and would like to thank all the health care providers who participated in this study and responded to our interviews.

\section{Authors' contributions}

CMK collected and analyzed the data and drafted the manuscript. LS developed the study proposal, performed data management and contributed to drafting the manuscript.
AAOS developed the knowledge, attitudes and practices survey instrument and contributed to data analysis. DD supervised data collection. HMB reviewed the study design and revised subsequent drafts of the manuscript. JG conceived of the study in conjunction with DD, developed the research design and revised the paper. CMK, LS, JG, AAOS, HMB and DD critically reviewed the entire study and made useful contributions in the analysis and interpretation of data. All authors read and approved the final paper.

\section{Disclosure}

The authors have no conflicts of interest to disclose in this work.

\section{References}

1. Ferlay J, Shin H-R, Bray F, Forman D, Mathers C, Parkin DM. Estimates of worldwide burden of cancer in 2008: GLOBOCAN 2008. Int J Cancer. 2010;127(12):2893-2917.

2. WHO/ICO. Human Papillomavirus and Related Cancers Summary Report 2015. WHO/ICO Information Centre; 2010. Available from: http://www. hpvcentre.net/statistics/reports/XWX.pdf. Accessed June 22, 2015.

3. Blumenthal PD, Gaffikin L. Cervical cancer prevention: making programs more appropriate and pragmatic. JAMA. 2005;294(17):2225-2228.

4. Brinton LA, Hamman RF, Huggins GR, et al. Sexual and reproductive risk factors for invasive squamous cell cervical cancer. J Natl Cancer Inst. 1987;79(1):23-30.

5. Chelimo C, Wouldes TA, Cameron LD, Elwood JM. Risk factors for and prevention of human papillomaviruses (HPV), genital warts and cervical cancer. J Infect. 2013;66(3):207-217.

6. WHO/ICO. Summary report on HPV and cervical cancer statistics in Ethiopia; 2015. WHO/ICO. Available from: http://www.hpvcentre.net/ statistics/reports/ETH.pdf. Accessed June 22, 2015.

7. Getahun F, Mazengia F, Abuhay M, Birhanu Z. Comprehensive knowledge about cervical cancer is low among women in Northwest Ethiopia. BMC Cancer. 2013;13:2.

8. Birhanu Z, Abdissa A, Belachew T, et al. Health seeking behavior for cervical cancer in Ethiopia: a qualitative study. Int J Equity Health. 2012; 11:83.

9. Hailu A, Mariam DH. Patient side cost and its predictors for cervical cancer in Ethiopia: a cross sectional hospital based study. BMC Cancer. 2013;13:69.

10. Goldie SJ, Gaffikin L, Goldhaber-Fiebert JD, et al. Cost-effectiveness of cervical-cancer screening in five developing countries. N Engl J Med. 2005;353(20):2158-2168.

11. Harris PA, Taylor R, Thielke R, Payne J, Gonzalez N, Conde JG. Research electronic data capture (REDCap) - a metadata-driven methodology and workflow process for providing translational research informatics support. J Biomed Inform. 2009;42(2):377-381.

12. Remes P, Selestine V, Changalucha J, et al. A Qualitative study of HPV vaccine acceptability among health workers, teachers, parents, female pupils, and religious leaders in northwest Tanzania. Vaccine. 2012;30(36):5363-5367.

13. Sankaranarayanan R, Budukh AM, Rajkumar R. Effective screening programmes for cervical cancer in low- and middle-income developing countries. Bull World Health Organ. 2001;79(10):954-962.

14. Qiao YL, Sellors JW, Eder PS, et al. A new HPV-DNA test for cervicalcancer screening in developing regions: a cross-sectional study of clinical accuracy in rural China. Lancet Oncol. 2008;9(10):929-936.

15. Gaffikin L, Lauterbach M, Blumenthal PD. Performance of visual inspection with acetic acid for cervical cancer screening: a qualitative summary of evidence to date. Obstet Gynecol Surv. 2003;58(8):543-550. 
16. Sankaranarayanan R, Basu P, Wesley RS, et al. Accuracy of visual screening for cervical neoplasia: Results from an IARC multicentre study in India and Africa. Int J Cancer. 2004;110(6):907-913.

17. Denny L, Kuhn L, De Souza M, Pollack AE, Dupree W, Wright TC Jr. Screen-and-treat approaches for cervical cancer prevention in lowresource settings: a randomized controlled trial. JAMA. 2005;294(17): 2173-2181.

18. Gaffikin L, Blumenthal PD, Emerson M, Limpaphayom K; Royal Thai College of Obstetricians and Gynaecologists (RTCOG)/JHPIEGO Corporation Cervical Cancer Prevention Group [corrected]. Safety, acceptability, and feasibility of a single-visit approach to cervical-cancer prevention in rural Thailand: a demonstration project. Lancet. 2003; 361(9360):814-820.

19. Akinwuntan AL, Adesina OA, Okolo CA, et al. Correlation of cervical cytology and visual inspection with acetic acid in HIV-positive women. J Obstet Gynaecol. 2008;28(6):638-641.

20. Sankaranarayanan R, Nene BM, Shastri SS, et al. HPV screening for cervical cancer in rural India. N Engl J Med. 2009;360(14):1385-1394.
21. Pfaendler KS, Mwanahamuntu MH, Sahasrabuddhe VV, Mudenda V, Stringer JS, Parham GP. Management of cryotherapy-ineligible women in a "screen-and-treat" cervical cancer prevention program targeting HIV-infected women in Zambia: lessons from the field. Gynecol Oncol. 2008;110(3):402-407.

22. Sankaranarayanan R, Rajkumar R, Esmy PO, et al. Effectiveness, safety and acceptability of 'see and treat' with cryotherapy by nurses in a cervical screening study in India. Br J Cancer. 2007;96(5):738-743.

23. Masch R, Ditzian LR, April AK, Maza M, Peralta E, Cremer ML. Cervical cancer screening and treatment training course in E1 Salvador: experience and lessons learned. J Womens Health (Larchmt). 2011; 20(9):1357-1361.

24. Sankaranarayanan R, Esmy PO, Rajkumar R, et al. Effect of visual screening on cervical cancer incidence and mortality in Tamil Nadu, India: a cluster-randomised trial. Lancet. 2007;370(9585):398-406.
International Journal of Women's Health

\section{Publish your work in this journal}

The International Journal of Women's Health is an international, peerreviewed open-access journal publishing original research, reports, editorials, reviews and commentaries on all aspects of women's healthcare including gynecology, obstetrics, and breast cancer. The manuscript management system is completely online and includes

\section{Dovepress}

a very quick and fair peer-review system, which is all easy to use. Visit http://www.dovepress.com/testimonials.php to read real quotes from published authors. 